\title{
Betonarme İstinat Duvarları için Maliyet Tahmin Modelleri
}

\author{
Uğur Dağdeviren ${ }^{1 *}$, Burak Kaymak ${ }^{2}$
}

Geliş / Received: 14/11/2019

Revize / Revised: 23/12/2019

Kabul / Accepted: 03/01/2020

$\overline{\mathbf{o z}}$

Betonarme istinat duvarları, karayolu, demiryolu, bina vb. birçok inşaat mühendisliği projesinde inşa edilmektedir. Betonarme istinat duvarlarının tasarımında birçok farklı tasarım kısıtlaması göz önünde bulundurulmalıdır. Geleneksel yaklaşımda, tasarım değişkenleri optimum tasarımı sağlamak için deneme yanılma işlemi ile birç̧ok kez kontrol edilir, bu nedenle proje yöneticileri zamandan tasarruf etmek için optimizasyon teknikleri kullanmak durumundadır. İnşaat mühendisliği projelerindeki diğer bir önemli konu, ihale süreci için inşaat öncesi proje maliyetinin doğru olarak tahmin edilmesidir. Çalışmanın ilk aşamasında, duvar yükseklikleri, sürşarj yükleri ve dolgu zemininin içsel sürtünme açılarının farklı kombinasyonlarında, sağlam zemin tabakasına oturan betonarme istinat duvarı için 125 optimizasyon problemi modifiye yapay arı koloni algoritması kullanılarak analiz edilmiş ve minimum maliyetler belirlenmiştir. Daha sonra, duvarın minimum maliyet tahmini için çoklu regresyon ve yapay sinir ağı modelleri sunulmuştur. Önerilen modellerden elde edilen maliyet tahminleri, modifiye yapay arı koloni algoritması tarafindan hesaplanan değerlerle büyük ölçüde uyumludur. Tahmin edilen ve hesaplanan minimum maliyetler arasındaki hata değerleri neredeyse sıfırdır. Sonuçlar, önerilen modellerin, sağlam zemin tabakasına oturan betonarme istinat duvarlarının minimum maliyet tahmini için başarıyla kullanılabileceğini göstermektedir.

Anahtar Kelimeler- Yapay Sinir Ağı, Maliyet Tahmini, Modifiye Yapay Arı Koloni Algoritması, Regresyon Modeli, İstinat Duvarı.

\footnotetext{
1*Sorumlu yazar iletişim: ugur.dagdeviren@dpu.edu.tr (https://orcid.org/0000-0002-4760-6574)

Department of Civil Engineering, Kütahya Dumlupınar University, 43100, Kütahya

2illetişim: burak.kaymak@dpu.edu.tr (https://orcid.org/0000-0002-1318-0456)

Department of Civil Engineering, Kütahya Dumlupınar University, 43100, Kütahya
} 


\title{
Cost Estimation Models for the Reinforced Concrete Retaining Walls
}

\begin{abstract}
The reinforced concrete retaining walls (RCRWs) are constructed many civil engineering projects such as highway, railway, building etc. Many different design constraints must be considered in the design of RCRWs. In the traditional approach, the design variables are controlled many times by the trial-error process to provide the optimum design; thus, the optimization techniques must be used to save on time for project managers. The other important subject in civil engineering projects is to estimate correctly the cost of the project of the tender process before the construction. In the first stage of the study, 125 optimization problems for the RCRW, which are sitting on the strong soil layer, are analyzed for different combinations of wall heights, surcharge loads and internal friction angles of the backfill soil by use of the modified artificial bee colony (ABC) algorithm, and minimum costs are determined. Then, the multiple regression and artificial neural network models are presented for the minimum cost estimation of the wall. The cost estimations obtained from the proposed models are in great agreement with the calculated values by the modified ABC algorithm. The error values between predicted and calculated minimum costs are almost zero. The results show that the proposed models can be successfully used for the minimum cost estimation of the RCRWs sitting on the strong soil layer.
\end{abstract}

Keywords- Artificial Neural Network, Cost Estimation, Modified Artificial Bee Colony Algorithm, Regression Model, Retaining Wall. 


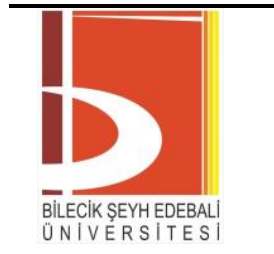

BŞEÜ Fen Bilimleri Dergisi

7. Cilt - Milli Mücadele ve TBMM'nin

Açılışının 100. Yılı Anısına-100. Yıl Özel

Say1s1

9-26, 2020

BSEU Journal of Science

DOI: $10.35193 /$ bseufbd. 646668

e-ISSN: 2458-7575 (http://dergipark.gov.tr/bseufbd)

\section{INTRODUCTION}

The reinforced concrete retaining wall (RCRW) is one of the commonly used retaining structures to support earth with the change in ground elevation. The usage areas of these structures are quite wide, such as highways, railways, bridges, buildings, etc. The optimum design of RCRWs can be achieved by considering several different design criteria at the same time. The main purpose of the problem is to determine the most economical wall dimensions and reinforcements that meet these design constraints. By this purpose, the crosssectional dimensions of the wall and reinforcement ratios in the wall sections are continuously revised by the trial-error method, and it is checked whether the design constraints are exceeded at every turn. These procedures are repeated heaps of times until the most economical wall design is achieved under the design requirements. Therefore, the design of RCRWs is becoming one of the important optimization problems.

The optimization problems are generally solved by meta-heuristic optimization methods based on nature-inspired ideas in recent years because they have significant advantages such as ease of use, convergence speed, and finding the optimum value. Particle swarm optimization (PSO), genetic algorithm (GA), differential evolution algorithm (DE), artificial bee colony algorithm (ABC), bacterial foraging optimization (BFO), gravitational search algorithm (GSA), and many more are only a few of the optimization algorithm. The artificial bee colony $(\mathrm{ABC})$ algorithm is an optimization algorithm based on the behavior of honeybee swarms developed by Karaboga [1]. Karaboga and Basturk [2] showed that the ABC algorithm performs better than some algorithms, such as differential evolution (DE), particle swarm optimization (PSO), and evolutionary algorithm (EA), to solve the multimodal engineering problems with high dimensionality. Bolaji et al. [3] pointed out that the ABC algorithm has some advantages, such as simplicity, flexibility, robustness, ease of hybridization, and a few control parameters. The algorithm has been modified to increase the convergence speed many times for constrained and real-parameter optimization problems [4-5]. In recent years, the ABC algorithm has been successfully implemented in civil engineering optimization problems such as optimum design of braced steel frame [6], pavement resurfacing problem [7], the structural damage detection problem [8], evaluation of the compressive strength of concrete specimens using laboratory experiments [9], optimization of the cost of project schedules in construction [10].

Many different meta-heuristic optimization techniques are applied to optimize the design of RCRWs, having a minimum cost or weight. Ceranic et al. [11] reported the application of simulated annealing (SA) algorithm to minimize the cost design of RCRWs. Yepes et al. [12] made a parametric study to examine the effect of the main factors affecting optimum walls using the Simulated Annealing (SA) algorithm. Ghazavi and Bonab [13] used Ant Colony Optimization (ACO), and Ghazavi and Salavati [14] proposed Bacterial Foraging Optimization (BFO) algorithm to optimize the RCRWs. Big bang-big crunch (BB-BC) optimization algorithm is applied to the low-cost and low-weight design of RCRW by Camp and Akin [15]. Pei and Xia [16] presented heuristic algorithms, including Genetic Algorithm (GA), particle swarm optimization (PSO) and Simulated Annealing (SA) algorithm to solve the optimization problem. Kaveh and Khayatazad [17] presented the optimal design of a cantilever retaining wall under different earthquake loading conditions using by Ray Optimization (RA). Mergos and Mantoglou [18] applied the flower pollination algorithm (FPA) to the optimum design of RCRWs. These studies in the literature have generally focused on the applicability and performance of different optimization techniques on the design of RCRWs.

The estimation of the cost of an engineering project is one of the most important factors affecting whether a project becomes successful or not. The estimation cost is widely used to determine the budget and the threshold value of the contract. Because the accuracy of the cost estimation of the project affects many factors such as the project's decision, construction scale, working plan, it has a great significance for project management. If the estimation cost is extremely different from actual cost, then it may cause the elimination of economically advantageous tenders. For this reason, it is important to determine the minimum cost of the retaining walls that are frequently built-in construction works. Many researchers are focused on the prediction of construction cost in the early phases of building design processes [19-24]. 
The most effective parameters affecting the cost of the RCRW sitting on the strong soil layer are the height of the wall, the surcharge load, and the internal friction angle of the backfill soil [15, 25-28]. In this study, the effects of these parameters on the minimum cost of the RCRW are investigated by using the modified ABC algorithm developed by Karaboga and Akay [4]. Structural design is performed based on ACI 318-05 [29]. 125 optimization problems are analyzed for different input parameter combinations. The results of the analyses are used to establish a second-order multiple regression model with three independent variables and the artificial neural network (ANN) model between the input parameters and minimum cost of the RCRW. The evaluations show that the minimum cost of the RCRW is successfully predicted by the proposed both regression model and ANN model.

The remaining parts of the article are organized as follows: The definition of the optimization problem is described in Section 2. The fundamentals of the used methodology for the ABC algorithm, multiple regression, and artificial neural network are briefly introduced in Section 3. Section 4 provides the results of the optimization analyses, and proposed estimation models are developed in Section 5. Finally, the conclusion of this study is presented and discussed in Section 6.

\section{DEFINITION OF THE OPTIMIZATION PROBLEM}

\section{A. Formulation of the Optimization Problem}

The reinforced concrete retaining wall (RCRW) is designed to support the lateral stresses such as soil and water pressure. The RCRW is formed from the stem and foundation of the wall as shown in Figure 1. The lateral pressures acting on the wall, which are active and passive earth pressures $\left(\mathrm{P}_{\mathrm{a}}\right.$ and $\left.\mathrm{P}_{\mathrm{p}}\right)$ and pressures induced by surcharge $\left(\mathrm{P}_{\mathrm{q}}\right)$, are generally calculated based on Rankine's or Coulomb's earth pressure theory. Unlike Coulomb's theory, Rankine's earth pressure theory, which is often preferred in design, assumes that there is no wall friction. The vertical forces acting on the RCRW are the weight of wall components $\left(\mathrm{W}_{\mathrm{w}}\right)$, the weight of the backfill soil $\left(\mathrm{W}_{\mathrm{s}}\right)$, and the base force due to base stress below the foundation $\left(\mathrm{P}_{\mathrm{b}}\right)$.

The design of the RCRW is based on external and internal stability analyses. The safety of the wall in terms of external stability means that the wall will be reliable against rotation around the toe, sliding along the foundation, and against bearing failure of the wall foundation and tensile stresses. In the external stability analysis, some preventive effects such as passive earth pressure, surcharge load above the heel, and the weight of soil on the toe are generally neglected.

The factor of safety against overturning of the wall can be defined as the ratio of the resisting moments against overturning $\left(\Sigma \mathrm{M}_{\mathrm{R}}\right)$ to overturning moments $\left(\Sigma \mathrm{M}_{\mathrm{O}}\right)$. The minimum factor of safety against overturning failure as given Eq. (1) must be at least 1.5 for granular backfills.

$$
F S_{(\text {overturning) }}=\frac{\sum M_{R}}{\sum M_{O}}
$$

The safety against sliding along the foundation of the wall can be calculated from Eq. (2). It is desired that the factor of safety for sliding must be at least 1.5 .

$$
F S_{(\text {sliding })}=\frac{\sum F_{R}}{\sum F_{S}}
$$

where, $\Sigma F_{S}$ is the sum of the sliding horizontal forces, and $\Sigma F_{R}$ is the resisting forces against sliding, which is determined from Eq. (3). 


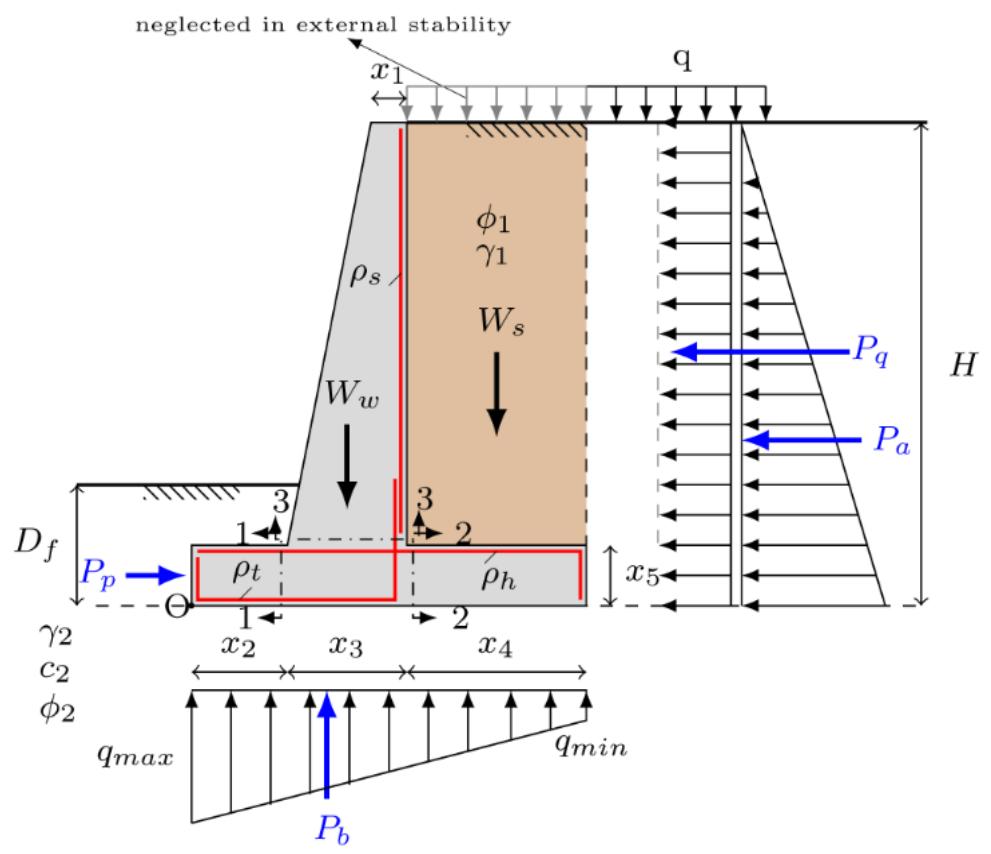

Figure 1. The design variables and forces acting on the RCRW

$$
\Sigma F_{R}=P_{p}+\Sigma V \cdot \tan \left(\phi_{a}\right)+B \cdot c_{a}
$$

$\Sigma \mathrm{V}$ is the total vertical load, $\mathrm{B}$ is the width of the foundation, $\phi_{\mathrm{a}}$ and $\mathrm{c}_{\mathrm{a}}$ are the friction angle and adhesion between the wall and soil in the base of the wall, which can be determined from the shear strength parameters of the foundation soil. $\mathrm{P}_{\mathrm{p}}$ is the passive earth force, and it will be a safe approach to neglect the effect of $\mathrm{P}_{\mathrm{p}}$ due to possible excavation and erosion.

The distance of the action point of the resultant vertical force acting on the foundation of the wall to the axis of symmetry can be determined from Eq. (4), which is called the eccentricity. The under the foundation is not uniform due to eccentricity. If the eccentricity is smaller the $\mathrm{B} / 6$, then the base stress distribution will be trapezoidal, as shown in Figure 1. The maximum $\left(\mathrm{q}_{\max }\right)$ and minimum $\left(\mathrm{q}_{\min }\right)$ base stresses are calculated as given in Eq. (5). The maximum base stresses below the foundation of the wall must be safely provided against the ultimate bearing capacity of the foundation soil. The factor of safety against bearing capacity failure can be determined as in Eq. (6), and it is desired that the factor of safety must be at least 3 . If the eccentricity becomes greater than $\mathrm{B} / 6$, then the tensile stress occurs below the foundation, which means that the foundation of the wall will separate from the base soil. It is not an acceptable case, and it is defined as the design constraint in this study, as shown in Eq. (7).

$$
\begin{aligned}
& e=\frac{B}{2}-\frac{\Sigma M_{R}-\Sigma M_{O}}{\Sigma V} \\
& q_{\min }=\frac{\Sigma V}{B}\left(1 \mp \frac{6 e}{B}\right) \\
& F S_{(\text {bearing) }}=\frac{q_{u l t}}{q_{\max }}
\end{aligned}
$$




$$
F S_{(\text {no-tension })}=\frac{B / 6}{e} \geq 1
$$

In the internal stability analysis, it is checked whether reinforced concrete sections are safe against flexure and shear failures or not. These analyses are generally performed for $1-1,2-2$, and 3-3 sections, as shown in Figure 1. If desired, the number of sections to be analyzed in the stem of the wall can be increased. The design shear force $\left(\mathrm{V}_{\mathrm{d}}\right)$ and design moment $\left(\mathrm{M}_{\mathrm{d}}\right)$ acting on these critical sections are determined by considering the load factors. They must not exceed the moment capacity $\left(M_{n}\right)$ and shear capacity $\left(V_{n}\right)$ for the reinforced concrete members calculated using Eq. (8) and Eq. (9) according to ACI 318-05 [29].

$$
\begin{aligned}
& M_{n}=\phi_{M} \cdot A_{s} \cdot f_{y} \cdot\left(d-\frac{a}{2}\right) \\
& V_{n}=\phi_{V} \cdot 0 \cdot 17 \cdot \sqrt{f_{c}} \cdot b \cdot d
\end{aligned}
$$

where the strength reduction factors are $\phi_{\mathrm{M}}=0.9$, and $\phi_{\mathrm{V}}=0.75 . \mathrm{f}_{\mathrm{y}}$ and $\mathrm{f}_{\mathrm{c}}$ are yield strength of steel and compressive strength of concrete, respectively. $b$ and $d$ are the width and effective thickness of the section, respectively. $\mathrm{a}$ is the depth of the compressive stress block. $\mathrm{A}_{\mathrm{s}}$ is the cross-section area of steel section. The reinforcement ratios $\left(\rho_{\mathrm{t}}, \rho_{\mathrm{h}}\right.$ and $\left.\rho_{\mathrm{s}}\right)$ in the sections must be between the minimum $\left(\rho_{\min }\right)$ and maximum $\left(\rho_{\max }\right)$ values, which are defined as in Eq. (10) and Eq. (11) according to ACI 318-05 [29].

$$
\begin{aligned}
& \rho_{\text {min }}=0.25 \frac{\sqrt{f_{c}}}{f_{y}} \geq \frac{1.4}{f_{y}} \\
& \rho_{\text {max }}=0.85 \beta_{1} \cdot \frac{f_{c}}{f_{y}} \cdot\left(\frac{600}{600+f_{y}}\right)
\end{aligned}
$$

\section{B. Design Variables and Constraints}

For the optimization problem discussed in this study, the cross-sectional dimensions of the wall and main reinforcement ratios $\left(\rho_{\mathrm{t}}, \rho_{\mathrm{h}}, \rho_{\mathrm{s}}\right)$ for critical sections are selected as design variables. The cross-sectional dimensions of the wall are the stem thicknesses at the top and bottom $\left(\mathrm{x}_{1}, \mathrm{x}_{3}\right)$, the widths of the toe and heel of the foundation $\left(\mathrm{x}_{2}, \mathrm{x}_{4}\right)$, and thickness of the foundation $\left(\mathrm{x}_{5}\right)$. The reinforcement design variables are the main reinforcement ratio of the toe $\left(\rho_{\mathrm{t}}\right)$, heel $\left(\rho_{\mathrm{h}}\right)$, and stem $\left(\rho_{\mathrm{s}}\right)$, which are shown in Figure 1. In the optimization analyses, the lower and upper limit values are defined based on construction limits, reference values in the literature, and algorithm requirements.

$$
\begin{aligned}
& 0.3 \leq x_{1}, x_{3} \leq 4.0 \mathrm{~m} \\
& 0.2 \leq x_{2}, x_{4}, x_{5} \leq 4.0 \mathrm{~m} \\
& \rho_{\text {min }} \leq \rho_{t}, \rho_{h}, \rho_{s} \leq \rho_{\text {max }}
\end{aligned}
$$

The backfill and foundation soil properties, the embedment depth of the foundation, the height of the wall, surcharge load, minimum factors of safety, concrete, and steel properties are regarded as the input data of the optimization problem. The heights of the wall, the surcharge loads and the internal friction angles of the backfill are used as independent variables in the optimization analyses in this study. The concrete strength class is selected C30/37, and the yield strength of steel is used $\mathrm{f}_{\mathrm{y}}=420 \mathrm{MPa}$ in analyses. The results obtained from previous parametric trials show that even if the cohesion and internal friction angle of foundation soil increase, the cost of the wall does not decrease further. Therefore, to reach the lowest possible cost of the wall, the foundation soil shear strength parameters are selected as high values. 
In this optimization problem, the design constraints are external stability, internal stability, and problemspecific geometric requirements. External stability constraints are overturning, sliding, bearing capacity, and no tension condition constraints, which are defined in Eq. (1)-(7). Internal stability constraints are bending and shear failure modes for the toe, heel, and stem, which are formulated in Eq. (8)-(9). The geometric requirement is related to the slope of the wall front face, which must not exceed 50:1 slope.

\section{Objective Function}

In this study, the objective function is to minimize the cost of the RCRW. If the costs of excavation, formwork, and compaction is considered to be almost identical with each other walls, which are the same wall height, then the objective function is given as follows:

$$
f(x)=C_{s t} \cdot W_{s t}+C_{c} \cdot V_{c, n e t}
$$

$C_{s t}$ and $C_{c}$ are the unit cost of steel and concrete, and they are used as $\$ 0.40 / \mathrm{kg}$ and as $\$ 40 / \mathrm{m}^{3}$, respectively [30]. $\mathrm{W}_{\mathrm{st}}$ is the weight of steel, and $\mathrm{V}_{\mathrm{c} \text {,net }}$ is the net volume of concrete per unit length of the wall.

\section{METHODOLOGY}

\section{A. Artificial Bee Colony Algorithm}

The artificial bee colony algorithm is one of the meta-heuristic optimization algorithms, which models the foraging behavior of honeybees. According to the algorithm proposed by Karaboga [1], there are three types of bees in the hive: employed bees, onlooker bees, and scout bees. Half of the bees in the hive serve as employed bees, and the other half assume the task of onlooker bees. In this study, the modified ABC algorithm proposed by Karaboga and Akay [4] is used. The pseudo-code of the modified ABC algorithm is given in Figure 2.
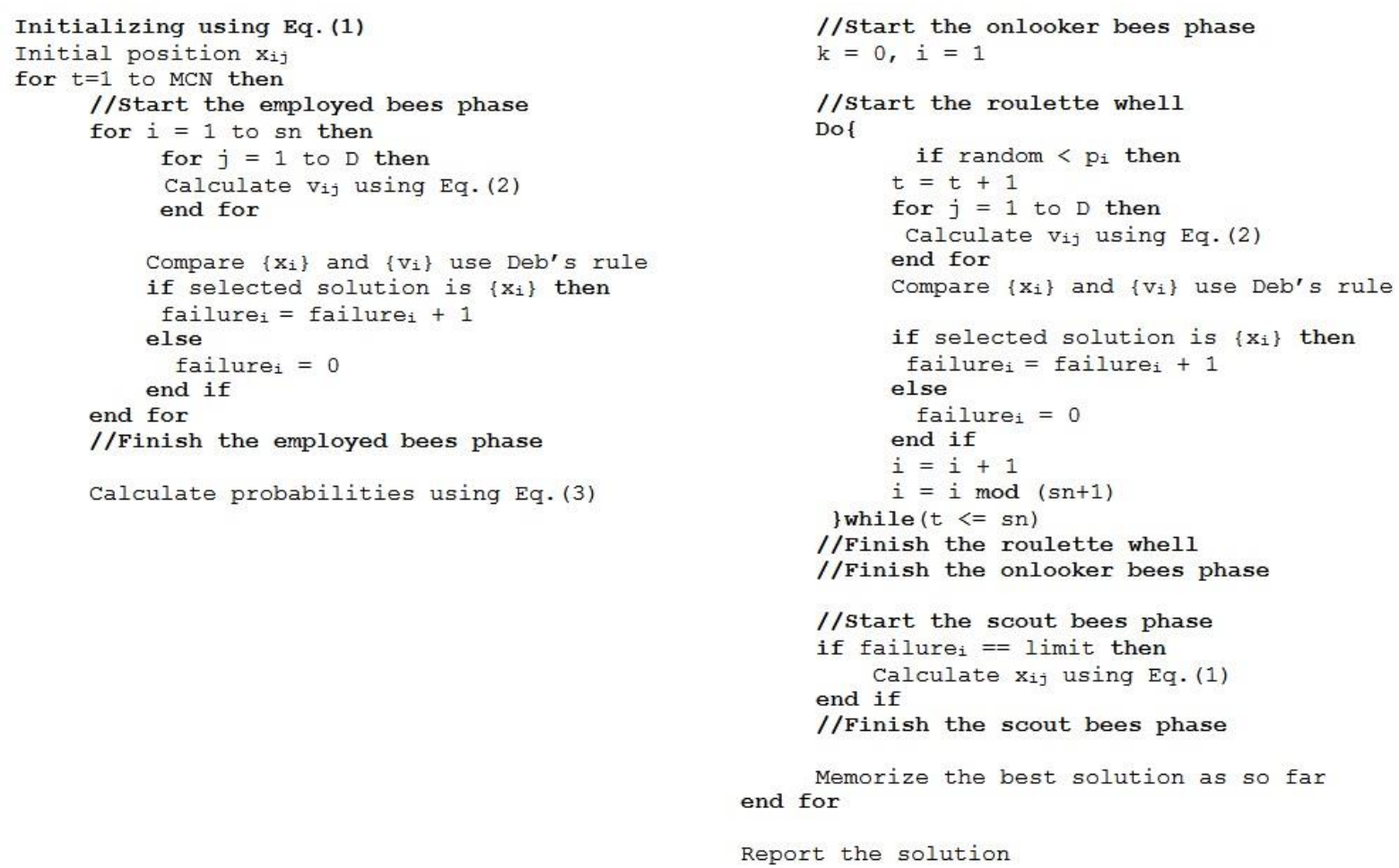

Figure 2. The pseudo-code of the modified ABC algorithm 
At the initialization phase, employed bees randomly distribute in the foraging area according to Eq. (14), and start to search for food. In Eq. (14), $\mathrm{x}_{\mathrm{ij}}$ denotes the $\mathrm{j}$ component of the $\mathrm{i}^{\text {th }}$ bee, $\mathrm{x}_{\mathrm{lj}}$ and $\mathrm{x}_{\mathrm{uj}}$ denote the minimum and maximum values of the $\mathrm{j}$ component.

$$
x_{i j}=x_{l j}+\operatorname{rand}(0,1) \times\left(x_{u j}-x_{l j}\right)
$$

Employed bees determine the location of the food sources $\left(\mathrm{x}_{\mathrm{ij}}\right)$ in the initialization state, then they search for new food sources $\left(\mathrm{v}_{\mathrm{ij}}\right)$ around the old source according to Eq. (15).

$$
v_{i j}=\left\{\begin{array}{cc}
x_{i j}+\Phi_{i j}\left(x_{i j}-x_{k j}\right) & , R_{j}<M R \\
x_{i j} & , R_{j} \geq M R
\end{array}\right.
$$

where $\mathrm{v}_{\mathrm{ij}}$ denotes the $\mathrm{j}$ component (new food source) of the $\mathrm{i}^{\text {th }}$ onlooker bee. $\Phi_{\mathrm{ij}}$ has a random real value between $[-1,1]$, and $R_{j}$ has a random real value between $[0,1]$. The MR value is one of the parameters of the algorithm and is a real number selected between $[0,1]$. The indices $\mathrm{k}$ is a random integer value between $[0, \mathrm{sn}]$ and different from $\mathrm{i}$. sn is the number of employed bees in the colony. $\mathrm{x}_{\mathrm{kj}}$ denotes the $\mathrm{j}$ component of the $\mathrm{k}^{\text {th }}$ bee.

The selection of food sources between the two sources is made according to Deb's rule. According to Deb's rule for the minimization problems, smaller object function value $\left(f_{i}\right)$ for two feasible solutions is preferred. If one of the solutions is feasible and the other is infeasible, then the feasible point is considered the better solution. If both points are infeasible, the point, which has a lower violation value defined in Eq. (18), is selected as a better solution. When the new resource is not better than the old resource, the failure ${ }_{i}$ value is incremented by one.

After the employed bees return to the hive, the information is collected about the quality of food sources. Onlooker bees use the information obtained from employed bees to get a probability value for each food source given as Eq. (16).

$$
P_{i}= \begin{cases}0.5+\left(\text { fitness }_{i} / \sum_{j=1}^{s n} \text { fitness }_{j}\right) \times 0.5 & \text {, if solution is feasible } \\ \left(1-\text { violation }_{i} / \sum_{j=1}^{s n} \text { violation }_{j}\right) \times 0.5 & , \text { if solution is infeasible }\end{cases}
$$

In Eq. (16), $p_{i}$ represents the probability value of the $i^{\text {th }}$ food source. If the solution at the point $i$ is feasible, the fitness value is calculated using the Eq. (17), where $f_{i}$ is the objective function of the point $i$. If the

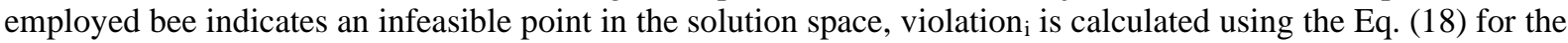
calculation of the probability value.

$$
\begin{aligned}
& \text { fitness }_{i}=\left\{\begin{array}{cc}
1 /\left(1+f_{i}\right) & , f_{i} \geq 0 \\
1+\left|f_{i}\right| & , f_{i}<0
\end{array}\right. \\
& \text { violation }_{i}=\sum_{j=1}^{q} \max \left\{0, g_{j}(x)\right\}+\sum_{j=1}^{m}\left|h_{j}(x)\right|
\end{aligned}
$$

In Eq. (18), $\mathrm{g}_{\mathrm{j}}(\mathrm{x})$ represents the negative surplus value of the normalized inequality constraint, and $\mathrm{h}_{\mathrm{j}}(\mathrm{x})$ represents the negative surplus value of the normalized equality constraint.

After calculating the probability value, the bees select the source from the candidate food sources using the roulette wheel method. The operation of the roulette wheel method is given in the pseudo-code in Figure 2. 
Onlooker bees that determine the food source to be visited by the roulette wheel method, they search for new sources around this source by using Eq. (15). Just like employed bees, onlooker bees prefer the better of the two sources by following Deb's rule. If the new source is not better than the old one, then failure ${ }_{i}$ is incremented by one. If the value of failure $i_{i}$ exceeds the limit value, the bee turns into a scout bee and starts searching for food at a random point in the solution space using Eq. (14). This phase is called the scout bee phase.

\section{B. Multiple Regression}

It is observed that some dependent variables are related to the other design variables in many engineering problems. Regression analysis is one of the most commonly used statistical technique for determining the relationship between the variables. The regression analysis aims to determine whether there is a significant relationship between the variables and to find a regression equation. Many different models (linear and nonlinear) are used to determine the fittest regression equation [31].

If the dependent variable $(\mathrm{y})$ is linearly affected by more than one independent variables $\left(\mathrm{x}_{1}, \mathrm{x}_{2}, \ldots, \mathrm{x}_{\mathrm{n}}\right)$, the multiple linear regression model is identified in Eq. (19).

$$
y_{i}=\beta_{0}+\beta_{1} x_{i, 1}+\beta_{2} x_{i, 2}+\ldots+\beta_{n} x_{i, n}+\varepsilon_{i}
$$

where $y_{i}$ is the value of the dependent variable in the $i^{\text {th }}$ observation. The parameters $\beta_{0}, \beta_{1}, \ldots, \beta_{\mathrm{n}}$ are regression coefficients for the independent variables. $\mathrm{n}$ is the number of independent variables. The predicted value $\left(\hat{y}_{\mathrm{i}}\right)$ by the regression equation may not always be equal to actual value $\left(\mathrm{y}_{\mathrm{i}}\right)$ in observation, and a random error $\left(\varepsilon_{i}\right)$ may occur, which is the difference between the observed and the predicted values.

If there is no linear relationship between the dependent and independent variables, different regression models, such as nonlinear models, can be used to estimate the dependent variable. The polynomial regression model is one of them. In this study, to estimate the minimum cost of the RCRWs, the second-order polynomial regression equation with three independent variables are used as defined in Eq. (20).

$$
E(Y)=\hat{y}=b_{0}+b_{1} x_{1}+b_{2} x_{2}+b_{3} x_{3}+b_{11} x_{1}^{2}+b_{22} x_{2}^{2}+b_{33} x_{3}^{2}+b_{12} x_{1} x_{2}+b_{13} x_{1} x_{3}+b_{23} x_{2} x_{3}
$$

where $b_{0}$ is the intercept of the regression model. $b_{1}, b_{2}$, and $b_{3}$ are linear effect coefficients. $b_{11}, b_{22}$, and $b_{33}$ are the quadratic effect coefficients, and $b_{12}, b_{13}$, and $b_{23}$ are interaction effect coefficients between pairs of independent variables. For the calculation of the regression coefficients in these models, the sum of squares of error will be minimized by using the least-squares method.

In this study, the coefficient of determination $\left(\mathrm{R}^{2}\right)$ and the root mean square error (RMSE) are used as statistical measure parameters to check the validity of the proposed regression model, which are defined in Eq. (21) and (22), respectively. In these definitions, $\mathrm{n}$ is the number of analyses in the database. If the coefficient of determination $\left(\mathrm{R}^{2}\right)$ approach to one, and the RMSE value is near to zero, then this means that the regression model estimates the dependent variable close to its actual values. 


$$
\begin{gathered}
R^{2}=1-\frac{\sum_{i=1}^{n}\left(y_{i}-\hat{y}_{i}\right)^{2}}{\sum_{i=1}^{n}\left(y_{i}-\bar{y}\right)^{2}} \\
R M S E=\sqrt{\frac{\sum_{i=1}^{n}\left(y_{i}-\hat{y}_{i}\right)^{2}}{n}}
\end{gathered}
$$

\section{Artificial Neural Networks}

Artificial neural networks (ANN) are described as a sub-branch of the artificial intelligence phenomenon, which was introduced in the 1940s. In the 1980s, the description of artificial neural networks began to be made with the question of whether the human brain could be made similar, and whether computers would be able to think like humans. Trying to imitate the work way of the human brain has been a starting point. Basically, it can be described as specialized structures for predicting which outputs to take from the experiences of a particular event to the input parameters of the relevant event. Perceptron, which is the basic unit of ANN, is defined as a structure that produces a single output from the parameters given as input. A diagram of the perceptron is represented in Figure 3.

The value obtained as a result of multiplying and summing the perceptron inputs by weights is passed through an activation function. The value to be entered into the activation function is the result of a linear function as shown in Eq. (23).

$$
y=\sum_{i}^{n} w_{i} x_{i}+b
$$

This linear result is converted to nonlinear form through the activation function. The activation function can be selected in various types. In practice, sigmoid, hyperbolic tangent, step function, ReLU, leaky ReLU, softmax, etc. functions are frequently used. The selection of the activation function is one of the parameters affecting network performance. The selection of the activation function is determined by operating the trial and error process, depending on the type of handled problem. The activation function must be differentiable and continuous.

Combining more than one of the perceptrons, which can be defined as a single-layer neural network, forms the structures described as ANN. In practice, the structure of ANN is generally given as an input layer, hidden layer or layers, and an output layer. Besides, ANN structures can be described.

The artificial neural network models make inferences about the desired event based on the input data. This event is called forward feed. The difference between the obtained inferences and the actual observation results describes the error. Backpropagation of the error requires updating the weights in the network. To reduce the error to a certain level, the above-described feed-forward and error backpropagation processes are repeatedly run. This process is called training of the neural network. Giving as many examples of the event as possible to the neural network during training provides more successful results in training of the network. 


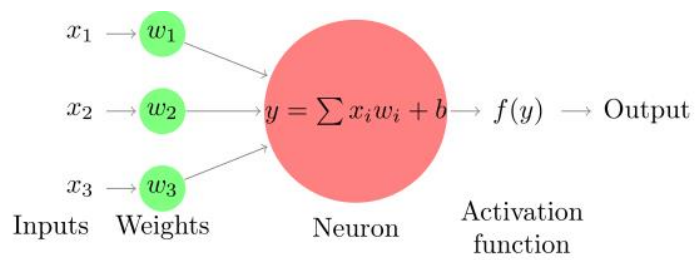

Figure 3. The basic unit of ANN perceptron structure

\section{THE RESULTS OF OPTIMIZATION ANALYSES}

In this study, to develop the cost estimation model, firstly, the effects of the wall height $(\mathrm{H})$, surcharge load $(q)$, and internal friction angle of the backfill soil $\left(\phi_{1}\right)$ on the minimum cost of RCRWs sitting on the strong soil layer must be investigated. For this aim, total of 125 optimization analyses are performed for different the heights of wall $(4,5,6,7$, and $8 \mathrm{~m})$, surcharge loads $(0,10,20,30$, and $40 \mathrm{kPa})$, and the internal friction angles of the backfill $\left(28,30,32,34\right.$, and $\left.36^{\circ}\right)$ by using the modified ABC algorithm. The depth of embedment of the foundation are chosen as $1.0 \mathrm{~m}$, and the passive forces are neglected. The unit weights of the backfill soil, foundation soil, and wall material are taken as 17,18 , and $23.5 \mathrm{kN} / \mathrm{m}^{3}$, respectively. The concrete strength class is selected $\mathrm{C} 30 / 37$, and the yield strength of steel is used $\mathrm{f}_{\mathrm{y}}=420 \mathrm{MPa}$ in analyses. The shear strength parameters of foundation soil are selected as $c_{2}=100 \mathrm{kPa}$ and $\phi_{2}=30^{\circ}$.

In order to assure high levels of stability, performance and repeatability of the modified ABC algorithm, the parameters of the algorithm are tested for different combinations. The appropriate parameter values are determined and used in the calculations (number of colonies, $\mathrm{CS}=100$; modification rate, $\mathrm{MR}=0.8$; limit $=$ 400 ; number of maximum cycles, $\mathrm{MCN}=1000$ ). The analyses are repeated 30 times to check the performance and repeatability of the algorithm for each problem. For the 125 optimization problems, the distribution of the objective functions obtained from 30 independent analyses are examined, and a histogram for the distribution of the coefficient of variation (COV) is shown in Figure 4. The COV value in $90 \%$ of the analyses is smaller than $0.37 \%$, and the maximum COV is $1.19 \%$. The repeatability of the algorithm is found sufficient for this study.

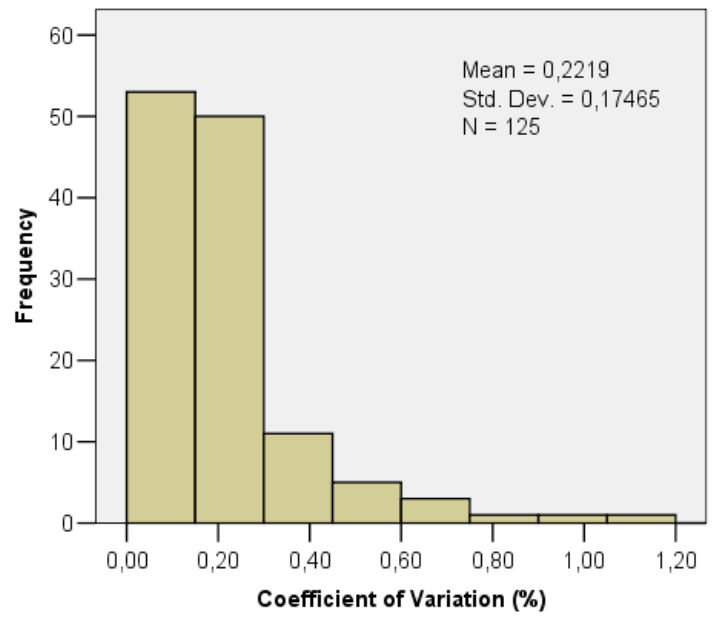

Figure 4. The distribution of the coefficients of variation for 30 independent analyses

The relationships between the surcharge load and minimum cost of the wall for the different internal friction angles of the backfill and wall heights are shown for two different wall heights in Figure 5. As is seen in 
Figure 5, the increase in the surcharge load causes an almost linear increase in the minimum cost of the wall. Especially, this linearity is becoming more pronounced when the height of the wall increases. If the surcharge load rises from 0 to $40 \mathrm{kPa}$, the minimum cost of the wall increases by $70 \%$ for the problem with $\phi_{1}=28^{\circ}$ and $\mathrm{H}$ $=4 \mathrm{~m}$, as shown in Figure 5a. While, the increment is $49 \%$ for the problem with $\phi_{1}=36^{\circ}$ and $\mathrm{H}=4 \mathrm{~m}$. This change remains between $48 \%$ and $52 \%$ for all internal friction angles for the wall, which height is $8 \mathrm{~m}$, as shown in Figure 5b. This change shows that the effect on the minimum cost of the surcharge load grows due to the internal friction angle in the wall with a low height. For the high walls, the trend of the minimum cost caused by surcharge increment is not significantly affected by the internal friction angle of the backfill.
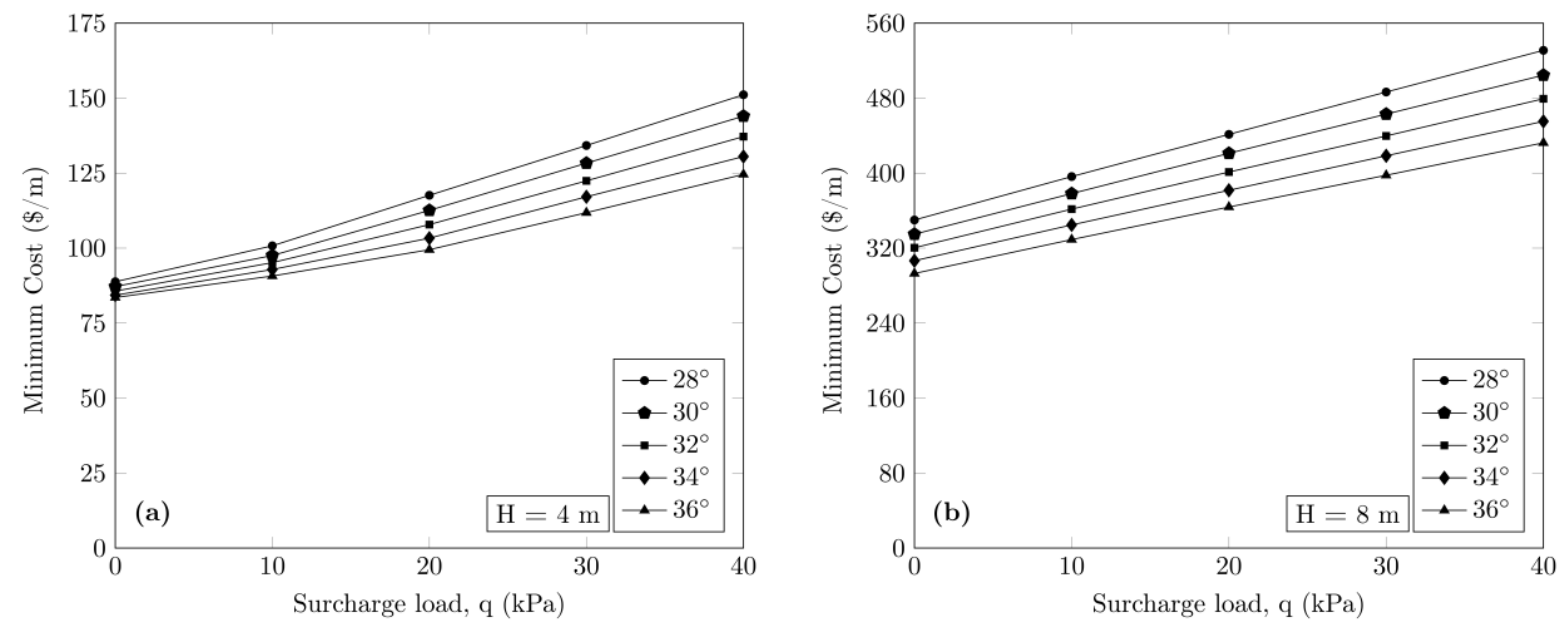

Figure 5. The effect of the surcharge load on minimum cost

Figure 6 indicates the variation of the minimum cost of the wall with the change in the internal friction angle of backfill $\left(\phi_{1}\right)$ for the $\mathrm{H}=6 \mathrm{~m}$ and $\mathrm{H}=7 \mathrm{~m}$ in wall height and varied surcharge loads. As the internal friction angle of the backfill increases, since lateral earth stresses decrease and the cost of the wall reduces. The downtrend is exactly linear, as shown in Figure 6. The increase in the internal friction angle from $28^{\circ}$ to $36^{\circ}$ causes on average $16 \%$ reduction in the cost of the wall.
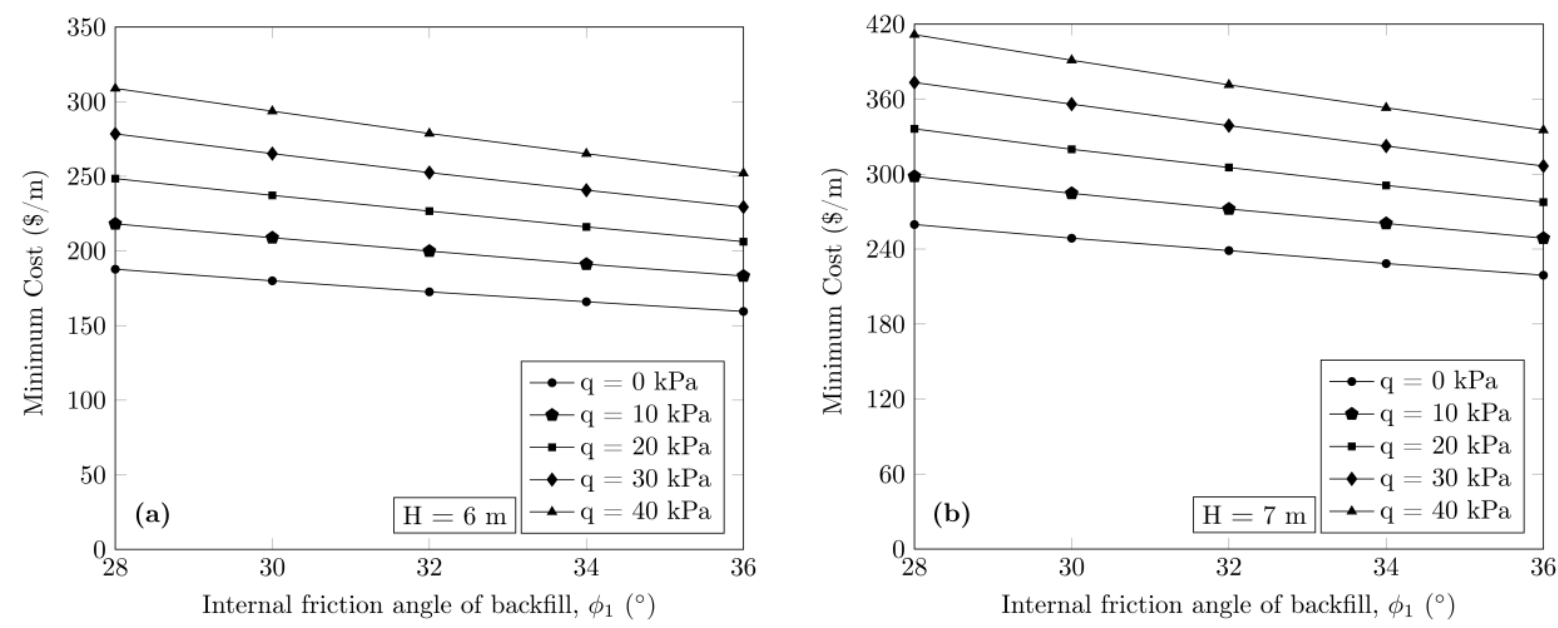

Figure 6. The effect of the internal friction angle of backfill on minimum cost 


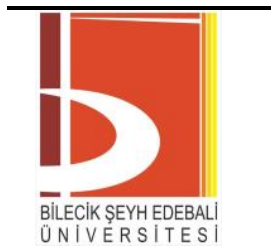

BŞEÜ Fen Bilimleri Dergisi

BSEU Journal of Science

7. Cilt - Milli Mücadele ve TBMM'nin

Açılışııın 100. Yılı Anısına-100. Yıl Özel

Sayıs1

9-26, 2020

e-ISSN: 2458-7575 (http://dergipark.gov.tr/bseufbd)

Figure 7 shows the variation between the minimum cost of the wall and the height of the wall. When the height of the wall is increased from $4 \mathrm{~m}$ to $8 \mathrm{~m}$, the minimum cost increases by $249 \%$ to $280 \%$ for $\phi_{1}=32^{\circ}$. The increment of the cost of the wall is $265 \%$ on average for all internal friction angles. It is understood that the main factor affecting the cost of the RCRW, which is sitting on the strong soil, is the height of the wall. The minimum cost increases as a second-order polynomial with increasing the height of the wall. Therefore, the effect of wall height on the minimum cost must be defined as the second order in the model to be developed.

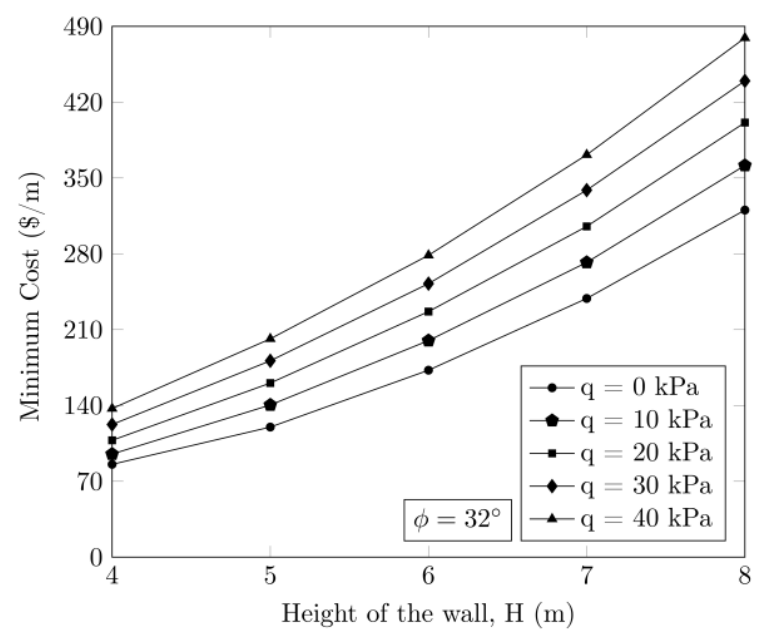

Figure 7. The effect of height of the wall on minimum cost

\section{THE COST ESTIMATION MODELS FOR THE RCRW}

\section{A. Regression Model}

In this study, the regression model is firstly established for the determination of the minimum cost of the wall. In the model, surcharge load (q), wall height $(\mathrm{H})$, and internal friction angle of backfill $\left(\phi_{1}\right)$ are selected as independent variables. Because the surcharge load (q) and internal friction angle of backfill ( $\left.\phi_{1}\right)$ cause a linear increase in the minimum cost of the RCRW as shown in Figure 5 and Figure 6, these parameters must be taken into account as a linear form in the regression model. The height of the wall affects the minimum cost of the RCRW quadratically, as shown in Figure 7. Therefore, the height of the wall is added to the model as a quadratic polynomial. Also, to increase the estimation capacity of the regression model, the interaction effect parameters between the $\mathrm{H}$ and $\mathrm{q}$; and $\mathrm{H}$ and $\phi_{1}$ are used in the model.

The used second-order model with three independent variables for the minimum cost of the wall $\left(\mathrm{C}_{\min }\right)$ is given as follows:

$$
C_{\min }=b_{0}+b_{1} \phi_{1}+b_{2} q+b_{3} H+b_{4} H^{2}+b_{5} \phi_{1} H+b_{6} q H
$$

where; the regression coefficients $\left(b_{0}, \ldots, b_{6}\right)$ are given in Table 1. In the multiple regression equation, $\phi_{1}$ is defined in degrees, $\mathrm{q}$ is defined in kilopascal, $\mathrm{H}$ is defined in meters, and the wall cost is calculated in $\$ / \mathrm{m}$.

As seen in Table 1, the multiple correlation coefficient value for the model is equal to $R=0.9993$. It is also clearly observed from Table 1 that the P-values in the three-parameter models are very smaller than 0.05 . It means that the regression model is statistically significant for all independent variables. Similarly, since the Fsignificant values are much less than 0.05 , it is understood that the minimum cost of the wall can be significantly predicted by the independent variables ( $\mathrm{q}, \phi_{1}$, and $\mathrm{H}$ ). Therefore, the regression model, where the surcharge load, 
the internal friction angle of the backfill, and the wall height are used as the predictor variables, can be accepted as strong models giving more realistic the minimum cost of the wall for the design of RCRWs. The multiple regression equation, which is proposed in this study for estimating the minimum cost of the wall, is summarized in Eq. (25).

$$
C_{\min }=-108.7763+5.8644 \phi_{1}-1.3314 q+33.0606 H+7.2843 H^{2}-1.9079 \phi_{1} H+0.6658 q H
$$

The comparison between the calculated minimum cost by the modified ABC algorithm and the predicted minimum cost by the regression analysis is shown in Figure 8. In this figure, it is seen that the predicted minimum cost values are very close to the calculated actual costs. For the regression model, the statistical performance evaluations based on $\mathrm{R}^{2}$ and RMSE values are given in Table 2. The coefficient of determination is equal to 0.9987 , and the root mean square error value is $4.22 \$ / \mathrm{m}$ for the model. The evaluations point out the existence of a statistically strong and significant relationship between the predicted and calculated minimum cost of the wall. Therefore, the proposed model can be used the estimation of the minimum cost of the RCRW sitting on the strong soil layers.

Table 1. The statistical evaluation of the regression model

\begin{tabular}{cccccc}
\hline Variables & Coefficients & t Stat & P-value & Multiple R & Sign. F \\
\hline Intercept & -108.7763 & -5.35 & $<0.001$ & & \\
$\phi_{1}$ & 5.8644 & 10.08 & $<0.001$ & & \\
$\mathrm{q}$ & -1.3314 & -11.44 & $<0.001$ & & \\
$\mathrm{H}$ & 33.0606 & 8.10 & $<0.001$ & 0.9993 & $3.7 \mathrm{E}-167$ \\
$\mathrm{H}^{2}$ & 7.2843 & 32.28 & $<0.001$ & & \\
$\phi_{1} \mathrm{H}$ & -1.9079 & -20.21 & $<0.001$ & & \\
$\mathrm{qH}$ & 0.6658 & 35.27 & $<0.001$ & & \\
\hline
\end{tabular}

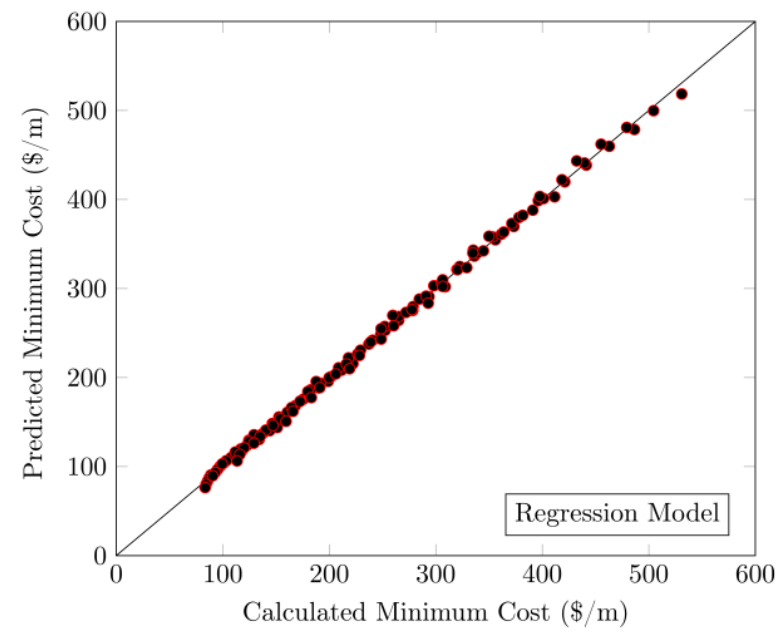

Figure 8. Comparison of calculated cost by $\mathrm{ABC}$ and predicted cost by the regression model

\section{B. Artificial Neural Network Model}

In this study, the artificial neural network model as a second model is performed to predict the minimum cost of the RCRW. Just as in the regression model, the surcharge load (q), the height of the wall $(\mathrm{H})$, and the internal friction angle of the backfill $\left(\phi_{1}\right)$ are selected as input parameters in the model, and the minimum 
cost of the wall is estimated as the output value. The network structure of the developed model in the present study is shown in Figure 9. The hidden layer in the network structure is created from one layer and ten neurons to provide the best performance.

The database has been randomly divided into three sets that are the training, validation, and test sets. $70 \%$ of the data are used for the training process. The remaining data are divided two-part to validate and test the model. The feed-forward backpropagation neural network model, which is the most used model, is implemented in the developed structure. The Levenberg-Marquardt algorithm, which is quite popular and considered as the best training algorithm, is preferred for training and adaption learning function in the update process of weight and bias values. The number of iterations is determined to decrease the mean square error by the trial-error method.

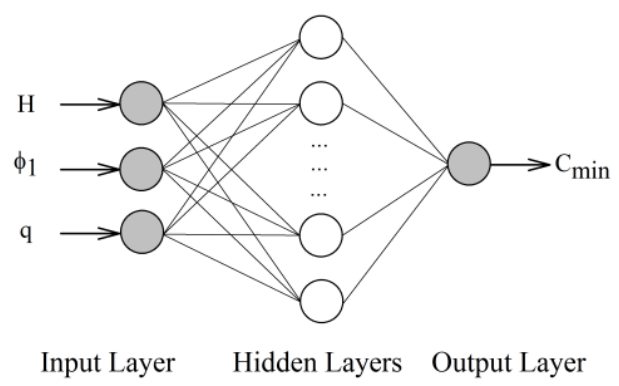

Figure 9. The structure of the developed ANN model

Table 2. Statistical evaluation of the regression analysis and the ANN model

\begin{tabular}{lcc}
\hline Model & $\mathbf{R}^{\mathbf{2}}$ & RMSE \\
\hline Multiple regression model & 0.9987 & $4.22 \$ / \mathrm{m}$ \\
\hline ANN model & 1.0000 & $0.30 \$ / \mathrm{m}$ \\
\hline
\end{tabular}

The predicted minimum cost obtained from the developed ANN model is compared with the calculated minimum cost value by the modified $\mathrm{ABC}$ algorithm as shown in Figure 10. The statistical performance evaluation criteria of the ANN model for 125 analyses are shown in Table 2. The coefficient of determination, $\mathrm{R}^{2}=1.0000$, and the error values are approximately zero. These values indicate that to be quite successful in estimating the minimum wall cost of the ANN model. It is thought that the difference between the RMSE values of the regression model and the ANN model proposed in this study is caused by the techniques of the models. In the ANN model, since the iterations are repeated many times to establish the most suitable model to minimize the errors in the learning process, the ANN model developed for the cost estimation of the RCRWs can provide more successful solutions than the regression model. 

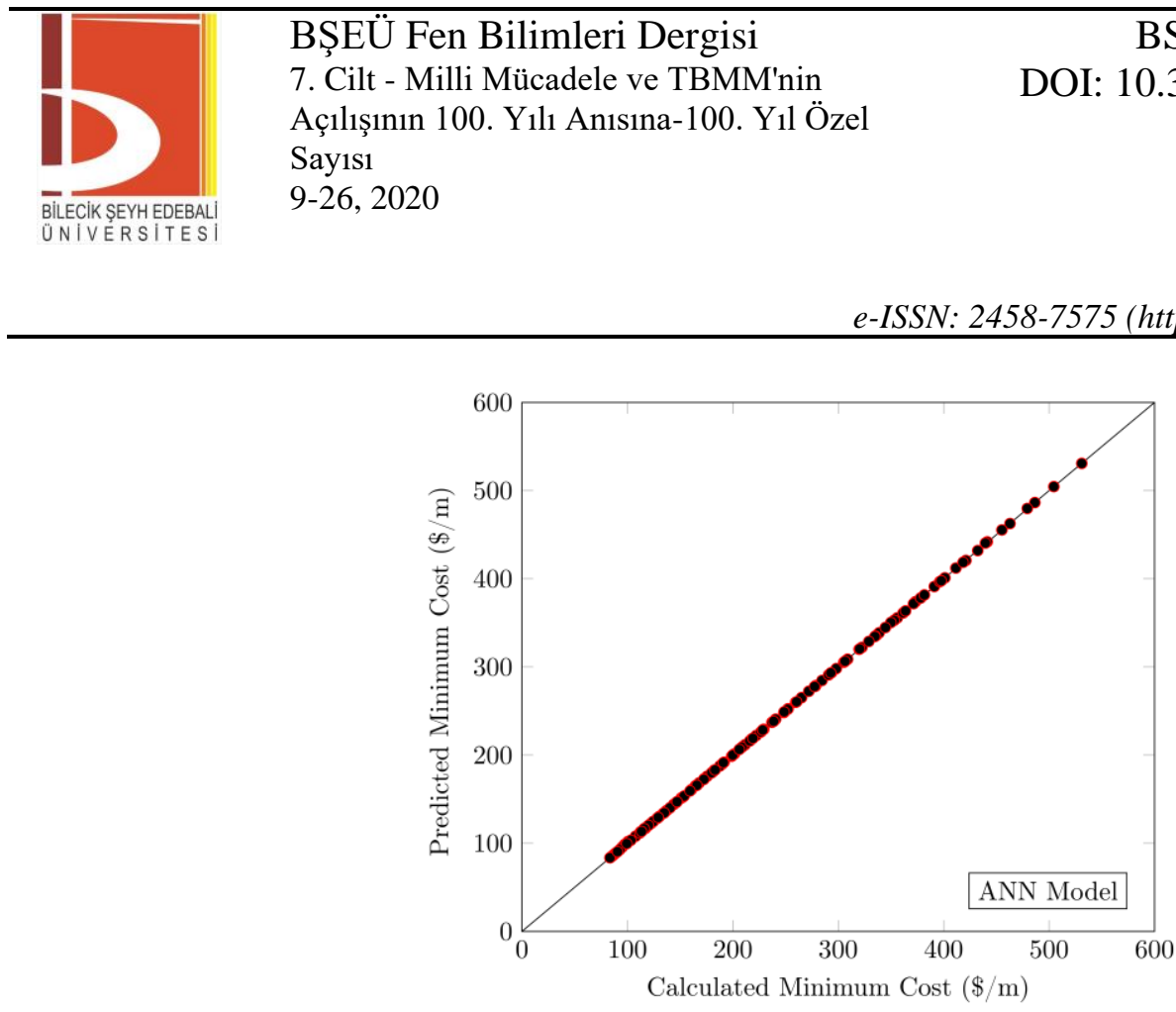

Figure 10. Comparison of calculated cost by $\mathrm{ABC}$ and predicted cost by ANN model

\section{CONCLUSIONS}

In this study, the cost estimation problem, which is one of the most influential factors of the project successful, is examined for reinforced concrete retaining walls. For this purpose, firstly, the tendency on optimum design of the RCRW of the design parameters such as surcharge load, the height of the wall, and the internal friction angle of the backfill is presented by using the modified ABC algorithm. At the end of the optimization analyses, it is observed that the increase in the surcharge load rises the cost of the wall between $48 \%$ and $70 \%$ depending on the height of the wall. This change is nearly linear for the walls higher than $4 \mathrm{~m}$ in height, essentially. The cost of the wall is inversely proportional to the increase in the internal friction angle of the backfill soil. This reduction is linear too. Besides, the effect of the height of the wall on the minimum cost is around $265 \%$. This effect is defined as the second-order in the regression model to be developed. In order to estimate the minimum cost of the RCRWs sitting on the strong soil layer, a multiple regression model and artificial neural network model are proposed based on the results obtained from the optimization analysis. The regression model is developed by using the second-order polynomial regression form with three independent variables. The coefficient of determination $\left(\mathrm{R}^{2}\right)$ and root mean square error (RMSE) for the regression model are found as 0.9987 and $4.22 \$ / \mathrm{m}$, respectively. In the ANN model, the minimum cost of the wall is predicted by the three-input layer, one hidden layer with 10 nodes, and one output layer with a network structure model. The results obtained from the ANN model are very close to the calculated values by the modified ABC algorithm. The coefficient of determination is determined as 1.0000, and the error value is nearly zero. When the analysis results are evaluated, it is seen that both the ANN model and the regression model have very high prediction ability. Due to the success of the proposed models, both models can be used in the early cost estimation of the projects of the RCRWs sitting on the strong soil layer.

\section{REFERENCES}

[1] Karaboga, D. (2005). An idea based on honey bee swarm form numerical optimization. Technical Report TR06. Erciyes University, Turkey.

[2] Karaboga, D. \& Basturk, B. (2008). On the performance of artificial bee colony (ABC) algorithm. Applied Soft Computing, 8(1), 687-697.

[3] Bolaji, A., Khander, A., Al-Betar, M. \& Awadallah, M. (2013). Artificial bee colony algorithm, its variants and applications: a survey. Journal of Theoretical and Applied Information Technology, 47(2), 434-459. 
[4] Karaboga, D. \& Akay, B. (2011). A modified artificial bee colony (ABC) algorithm for constrained optimization problems. Applied Soft Computing, 11(3), 3021-3031.

[5] Akay, B. \& Karaboga, D. (2012). A modified artificial bee colony algorithm for real-parameter optimization. Information Sciences, 192, 120-142.

[6] Mansouri, I., Soori, S., Amraie, H., Hu, J. \& Shahbazi, S. (2018). Performance based design optimum of CBFs using bee colony algorithm. Steel and Composite Structures, 27(5), 613-622.

[7] Panda, T. \& Swamy, A. (2018). An improved artificial bee colony algorithm for pavement resurfacing problem. International Journal of Pavement Research and Technology, 11(5), 509-516.

[8] Ding, Z., Yao, R., Li, J. \& Lu, Z. (2018). Structural damage identification based on modified artificial bee colony algorithm using modal data. Inverse Problems in Science and Engineering, 26(3), 422-442.

[9] Sun, L., Koopialipoor, M., Armaghani, D., Tarinejad, R. \& Tahir, M. (2019). Applying a meta-heuristic algorithm to predict and optimize compressive strength of concrete samples. Engineering with Computers, 1-13. DOI: https://doi.org/10.1007/s00366-019-00875-1.

[10] Sharma, T., Rajpurohit, J., Sharma, V. \& Prakash, D. (2019). Soft Computing: Theories and Applications. Advances in Intelligent Systems and Computing (V.742), Springer, Singapore.

[11] Ceranic , B., Fryer, C. \& Baines , R. (2001). An application of simulation annealing to the optimum design of reinforced concrete retaining structures. Computers \& Structures, 79(17), 1569-1581.

[12] Yepes, V., Gonzalez-Vidosa, F., Alcala , J. \& Villalba, P. (2008). A parametric study of optimum earthretaining walls by simulated annealing. Engineering Structures, 30(3), 821-830.

[13] Ghazavi, M. \& Bonab, S. (2011). Optimization of reinforced concrete retaining walls using ant colony method. ISGSR 2011, Vogt, Schuppener, 297-305.

[14] Ghazavi, M., \& Salavati, V. (2011). Sensitivity analysis and design of reinforced concrete cantilever retaining walls using bacterial foraging optimization algorithm. ISGSR 2011, Vogt, Schuppener, 307-314.

[15] Camp, C. \& Akin, A. (2012). Design of retaining walls using big bang-big crunch optimization. Journal of Structural Engineering, 138(3), 438-448.

[16] Pei, Y. \& Xia, Y. (2012). Design of reinforced cantilever retaining walls using heuristic optimization algorithms. Procedia Earth and Planetary Science, 5, 32-36.

[17] Kaveh, A. \& Khayatazad, M. (2014). Optimal design of cantilever retaining walls using ray optimization method. Iranian Journal of Science and Technology Transactions of Civil Engineering, 38(C1+), 261-274.

[18] Mergos, P. \& Mantoglou, F. (2019). Optimum design of reinforced concrete retaining walls with the flower pollination algorithm. Structural and Multidisciplinary Optimization, 1-11. DOI: https://doi.org/10.1007/s00158-019-02380-x.

[19] Günaydın, H. \& Doğan, S. (2004). A neural network approach for early cost estimation of structural systems of buildings. International Journal of Project Management, 22(7), 595-602.

[20] Wang, X.-Z., Duan, X.-C. \& Liu, J.-Y. (2010). Application of neural network in the cost estimation of highway engineering. Journal of Computers, 5(11), 1762-1766.

[21] Arafa , M. \& Alqedra, M. (2011). Early stage cost estimation of buildings construction projects using artificial neural networks. Journal of Artificial Intelligence, 4(1), 63-75. 
[22] Chandanshive, V. \& Kambekar, A. (2014). Prediction of early stage construction cost of building projects using artificial neural network. International Journal of Scientific \& Engineering Research, 5(7), 453-463.

[23] Gencer, H. (2017). Estimated cost calculation guidelines, problems in practice and a solution recommendation. Uluslararası Katılımlı 7. Inşaat Yönetimi Kongresi 2017, Samsun, 387-398.

[24] Juszczyk, M., Lesniak, A. \& Zima, K. (2018). ANN based approach for estimation of construction costs of sports fields. Complexity, Article ID 7952434, 1-11.

[25] Gandomi, A., Kashani, A., Roke, D. \& Mousavi, M. (2017). Optimization of retaining wall design using evolutionary algorithms. Structural and Multidisciplinary Optimization, 55(3), 809-825.

[26] Dağdeviren, U. \& Kaymak, B. (2018). Investigation of parameters affecting optimum cost design of reinforced concrete retaining. Journal of the Faculty of Engineering and Architecture of Gazi University, 33(1), 239-253.

[27] Mohammad, F. \& Ahmed, H. (2018). Optimum design of reinforced concrete cantilever retaining walls according to Eurocode 2 (EC2). Athens Journal of Technology and Engineering, 5(3), 277-296.

[28] Öztürk, H., \& Türkeli, E. (2019). Tabanında anahtar kesiti bulunan betonarme istinat duvarlarının jaya algoritmasıyla optimum tasarımı. Politeknik Dergisi, 22(2), 283-291.

[29] ACI 318-05. (2005). Building Code Requirements for Structural Concrete and Commentary. American Concrete Institute.

[30] Saribas, A., \& Erbatur, F. (1996). Optimization and Sensitivity of Retaining Structures. Journal of Geotechnical Engineering, 122(8), 649-656.

[31] Kutner, M.H., Nachtsheim, C.J., Neter, J. \& Li, W., (2005). Applied Linear Statistical Models, 5th Ed., McGraw-Hill/Irwin, p.1415. 